\title{
Acanthothecis sarcographoides (Ascomycota: Graphidaceae), a morphologically unique, new lichen species in the Atlantic Forest of northeastern Brazil
}

\author{
Marcela Eugenia da Silva Cáceres ${ }^{1}$ and Robert Lücking ${ }^{2}$
}

Received: 29 October, 2012. Accepted: 03 June, 2013

\begin{abstract}
A new species of Acanthothecis is described in the Atlantic Forest of northeastern Brazil. Unlike any other species in the genus, it has distinctly pseudo-stromatic ascomata that resemble those of the genus Sarcographa. However, its apically spinulose paraphyses, I-negative ascospores with thin endospore closely resemble those of other Acanthothecis species. A previous molecular phylogenetic analysis places the new species close to the type species of Acanthothecis, A. hololeucoides. The discovery of this unique new species underscores the importance of thorough biotic surveys in the Atlantic Forest of Brazil, where it is likely that many more unknown lichen species await discovery.
\end{abstract}

Key words: Mata do Crasto, Santa Luzia do Itanhy, Sergipe

\section{Introduction}

Graphidaceae is the largest family of tropical lichens, comprising nearly 2000 species world-wide (Staiger 2002; Frisch et al. 2006; Archer 2006, 2007, 2009; Lücking \& Rivas Plata 2008; Lücking 2009, 2012; Lücking et al. 2008, 2009; Rivas Plata et al. 2012, 2013; Mangold et al. 2009; Rivas Plata \& Lücking 2012; Sipman et al. 2012). It is the dominant element of lichen communities in tropical rain forests (Cáceres et al. 2007, 2008; Lücking et al. 2008; Rivas Plata et al. 2008). Originally, the family contained only species with lirellate ascomata, which were divided into eight genera depending on ascospore septation/color and ascomata organization (Wirth \& Hale 1963, 1978; Staiger 2002). Molecular phylogenetic analysis, however, showed that several other families had to be included and a new genus concept had to be established, leaving Graphidaceae with approximately 70 accepted genera (Staiger 2002; Frisch et al. 2006; Rivas Plata et al.2012, 2013). Several new genera, such as Malmographina, were described in Brazil (Cáceres et al. 2012).

One of the new genera is Acanthothecis Clem., a midsized genus of approximately 30 species with pantropical distribution, being rather abundant and speciose in Brazil, with 15 species reported and several recently described for the country (Staiger \& Kalb 1999; Staiger 2002; Dal-Forno \& Eliasaro 2009). Species of Acanthothecis are recognized by whitish, lirellate ascomata, mostly without exciple car- bonization, hymenium comprising paraphyses with finely spinulose apices, and ascospores with poorly developed endospores that do not react to iodine solution (Staiger \& Kalb 1999; Staiger 2002; Lücking \& Rivas-Plata 2008).

During a recent floristic survey of corticolous crustose lichens in fragments of the Atlantic Forest in the state of Sergipe in northeastern Brazil, a large number of lichen species were discovered, most of them crustose, and several apparently undescribed and new to science. One of the surveyed fragments was Mata do Crasto, which is one of the most important Atlantic Forest remnants in Sergipe, the smallest of all Brazilian states. It is a well-preserved Atlantic Forest relict of approximately $700 \mathrm{ha}$, located in the municipality of Santa Luzia do Itanhy, on the southern coast of the state, comprising a surprisingly rich lichen diversity (Cáceres 2007). In this paper, we describe a unique new species of Acanthothecis, similar to other species in the genus in terms of its hymenial and ascospore characters but differing in that it has distinctly pseudo-stromatic ascomata, resembling those of the unrelated genus Sarcographa, being the first Acanthothecis species known to have this characteristic.

\section{Material and methods}

The new species is described from specimens collected in Mata do Crasto. Identification and descriptive work was carried out in the Lichenology Laboratory, on the Itabaiana

\footnotetext{
${ }^{1}$ Universidade Federal de Sergipe, Departamento de Biociências, Itabaiana, SE, Brazil

${ }^{2}$ Department of Botany, The Field Museum, Chicago, Illinois, USA

${ }^{3}$ Author for correspondence: mscaceres@hotmail.com
} 
campus of the Federal University of Sergipe, and in the Department of Botany at the Field Museum, in Chicago. The images displayed in Fig. 1 were obtained with stereomicroscopes (EZ4 and MS5; Leica Microsystems, Bannockburn, IL, USA) and compound microscopes (DM500; Leica Microsystems-Axioskop 2; Carl Zeiss, Oberkochen, Germany-BH-2; Olympus, Tokyo, Japan-and VistaVision; VWR International, Radnor, PA, USA), in part connected to digital microscope cameras (ProgRes C3 and C5; Jenoptik, Jena, Germany). Images were captured with Nikon digital cameras (Coolpix 5400 and 8400; Nikon, Tokyo, Japan). Sections of thalli and ascomata were mounted in water, $10 \% \mathrm{KOH}$, and Lugol's iodine solution. All measurements were made in water. Chemical constituents were identified by thin-layer chromatography in solvent $\mathrm{C}$ ( $170 \mathrm{ml}$ toluene, $30 \mathrm{ml}$ glacial acetic acid) according to standardized methods (Culberson \& Ammann 1979; Elix \& Ernst-Russell 1993; Orange et al. 2001).

\section{Taxonomic treatment}

Acanthothecis sarcographoides M. Cáceres \& Lücking spec. nov. Mycobank No.: MB 803345. Diagnosis: Differing from all other species of Acanthothecis in the distinctly pseudo-stromatic ascomata; ascospores transversely septate, hyaline, fusiform, 15- to 21-septate with more or less rectangular lumina, 50.0-80.0 × 7.0-9.0 $\mu \mathrm{m}$; secondary substances absent. Type: Brazil. Sergipe: Santa Luzia do Itanhy, Mata do Crasto; c. 10.0 m alt.; on bark of tree; 17 April 2010, M.E.S. Cáceres 6785 (Holotype: ISE; isotype: F).

Thallus corticolous, grey-green, up to $10.0 \mathrm{~cm}$ diam. and 30.0-50.0 $\mu \mathrm{m}$ thick, continuous; surface smooth, shiny, with dense, prosoplectenchymatous cortex 7.0-12.0 $\mu \mathrm{m}$ thick; photobiont Trentepohlia, with angular-rounded to elongate cells $8.0-12.0 \times 5.0-7.0 \mu \mathrm{m}$ in size; photobiont layer lacking crystals, $20.0-30.0 \mu \mathrm{m}$ thick, in part endoperidermal; medulla indistinct. Lirellae organized
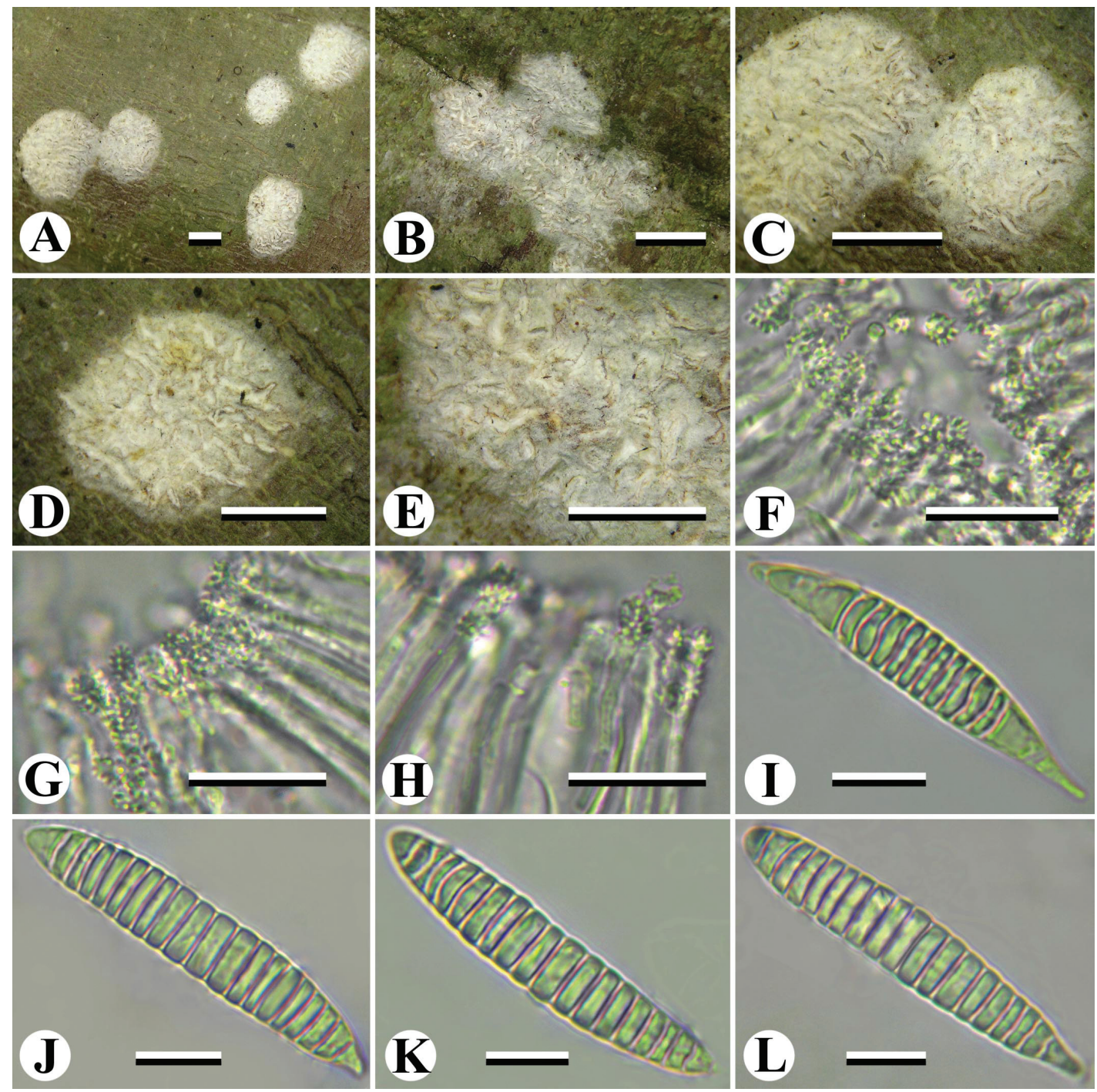

Figure 1. Acanthothecis sarcographoides (holotype). A-E. Thallus with pseudo-stromatic ascomata and pseudo-stromata enlarged showing individual lirellae. F-H. Apically spinulose paraphyses. I-L. Ascospores. Scales: $1 \mathrm{~mm}$ (A-E) and $10 \mu \mathrm{m}$ (F-L). 
in distinct, rounded to irregular pseudo-stromata that are sharply delineated from the surrounding thallus; pseudostromata 2.0-6.0 mm diam., white, 100.0-120.0 $\mu \mathrm{m}$ in height in section, densely incrusted with small, grey crystals that dissolve in $\mathrm{KOH}$ between the lirellae; lirellae dense within the pseudo-stromata but not aggregate, immersed, usually separated from each other by sterile pseudo-stromatic tissue filled with crystals, $0.5-1.0 \mathrm{~mm}$ long and $0.15-0.2 \mathrm{~mm}$ wide, straight or flexuose, usually unbranched, with indistinct, brown proper margin and thin, white thalline margin; disc mostly exposed but narrow, flesh-colored to pale brownish; proper margin indistinct, labia entire, thin, brown but usually covered by white pruina; thalline margin thin, white-pruinose, lacking algae. Excipulum thin, 20.0-30.0 $\mu \mathrm{m}$ wide, pale brown; laterally covered by crystalline pseudo-stromatic tissue lacking algae; hypothecium prosoplectenchymatous, 5.0-10.0 $\mu \mathrm{m}$ in height, colorless. Hymenium 100.0-110.0 $\mu \mathrm{m}$ in height, colorless, clear; epithecium 5.0-7.0 $\mu \mathrm{m}$ in height, colorless; paraphyses unbranched, apically distinctly spinulose; asci fusiform to clavate, 90.0-100.0 $\times 20.0-25.0 \mu \mathrm{m}$. Ascospores 8/ascus, irregularly arranged, fusiform, 15- to 21-septate, $50.0-80.0 \times 7.0-9.0 \mu \mathrm{m}$, with thin to very slightly thickened septa and mostly rectangular lumina, 7-9 times as long as wide, colorless, I-negative. Secondary chemistry: no substances detected by thin-layer chromatography (thallus surface or exposed medulla and thallus section were C-, K-, P-).

Distribution and ecology: This new species is thus far known only from the type locality in a fragment of Atlantic Forest. It appears to be a characteristic rain forest understory species growing in shaded situations on the smooth bark of tree trunks. It is likely endemic to the region, because it has not been found in any other Atlantic Forest fragment surveyed between Natal and Bahia.

Characterization and taxonomic relationships: Acanthothecis sarcographoides differs from all other species of Acanthothecis in that it has tiny lirellae arranged in distinct pseudo-stromata resembling those of the unrelated genus Sarcographa, which can be distinguished by its inspersed hymenium, brown, I-positive vine-red ascospores, and stictic acid chemistry (Staiger 2002). All other species of Acanthothecis have much larger, rather robust, solitary lirellae. However, the apically spinulose paraphyses and the I-negative, multiseptate ascospores of A. sarcographoides resemble those of other species within the genus. Most Acanthothecis species contain secondary substances, with the exception of $A$. obscura Staiger \& Kalb, which is, however, morphologically very different from A. sarcographoides (Staiger \& Kalb 1999; Staiger 2002; Lücking \& Rivas Plata 2008). The systematic placement of the new species is confirmed by a previous molecular phylogenetic study which places the species (as Acanthothecis spec. nov.) close to the type species of the genus, A. hololeucoides (Nyl.) Staiger \& Kalb (Rivas Plata et al. 2012).

\section{Acknowledgments}

This study was supported by grants from the (Brazilian) Conselho Nacional de Desenvolvimento Científico e Tecnológico (CNPq, National Council for Scientific and Technological Development) - Research Grant no. 501633/2009-0 to MESC - and from the (United States) National Science Foundation-Grant no. DEB-0715660 (Neotropical Epiphytic Microlichens - An Innovative Inventory of a Highly Diverse yet Little Known Group of Symbiotic Organisms) to The Field Museum (PI R. Lücking) and Grant no. DEB1025861 (ATM - Assembling a taxonomic monograph: The lichen family Graphidaceae) to The Field Museum (PI T. Lumbsch; Co-PI R. Lücking).

\section{References}

Archer, A.W. 2006. The lichen family Graphidaceae in Australia. Bibliotheca Lichenologica 94: 1-191.

Archer, A.W. 2007. Key and checklist for the lichen family Graphidaceae (lichenised Ascomycota) in the Solomon Islands. Systematics and Biodiversity 5: 9-22.

Archer, A.W. 2009. Graphidaceae. Flora of Australia 57: 84-194.

Cáceres, M.E.S. 2007. Corticolous crustose and microfoliose lichens of northeastern Brazil. Libri Botanici 22: 1-168.

Cáceres, M.E.S.; Lücking, R. \& Rambold, G. 2007. Phorophyte specificity and environmental parameters versus stochasticity as determinants for species composition of corticolous crustose lichen communities in the Atlantic rain forest of northeastern Brazil. Mycological Progress 6: 117-136.

Cáceres, M.E.S.; Lücking, R. \& Rambold, G. 2008. Corticolous microlichens in northeastern Brazil: habitat differentiation between coastal Mata Atlântica, Caatinga and Brejos de Altitude. The Bryologist 111: $98-117$.

Cáceres, M.E.S.; Rivas Plata, E. \& Lücking, R. 2012. Malmographina, a new genus for Graphina malmei (Ascomycota: Ostropales: Graphidaceae). Lichenologist 44: 115-120.

Culberson, C.F. \& Ammann, K. 1979. Standardmethode zur Dünnschichtchromatographie von Flechtensubstanzen. Herzogia 5: 1-24.

Dal Forno, M. \& Eliasaro, S. 2009. Two new species of Acanthothecis (lichenized Ascomycota) from Brazil. Mycotaxon 109: 43-47.

Elix, J.A. \& Ernst-Russell, K.D. 1993. A Catalogue of Standardized Thin Layer Chromatographic Data and Biosynthetic Relationships for Lichen Substances. 2nd ed. Canberra. Australian National University.

Frisch, A.; Kalb, K. \& Grube, M. 2006. Contributions towards a new systematics of the lichen family Thelotremataceae. Bibliotheca Lichenologica 92: 1-539.

Lücking, R. 2009. The taxonomy of the genus Graphis sensu Staiger (Ascomycota: Ostropales: Graphidaceae). Lichenologist 41: 319-362.

Lücking, R. 2012. Predicting species richness in tropical lichenized fungi with 'modular' combinations of character states. Biodiversity and Conservation 21: 2341-2360.

Lücking, R. \& Rivas-Plata, E. 2008. Clave y guía ilustrada para géneros de Graphidaceae. Glalia 1: 1-41.

Lücking, R.; Archer, A.W. \& Aptroot, A. 2009. A world-wide key to the genus Graphis (Ostropales: Graphidaceae). Lichenologist 41: 363-452.

Lücking, R.; Chaves, J.L.; Sipman, H.J.M.; Umaña, L. \& Aptroot, A. 2008. A first assessment of the Ticolichen biodiversity inventory in Costa Rica: the genus Graphis, with notes on the genus Hemithecium (Ascomycota: Ostropales: Graphidaceae). Fieldiana 46: 1-130.

Mangold, A.; Elix, J.A \& Lumbsch, H.T. 2009. Thelotremataceae. Flora of Australia 57: 195-420.

Orange, A.; James, P.W. \& White, F.J. 2001. Microchemical Methods for the Identification of Lichens. London, British Lichen Society. 
Rivas Plata, E. \& Lücking, R. 2012. High diversity of Graphidaceae (Ascomycota: Ostropales) in Amazonian Peru. Fungal Diversity [online first] doi: 10.1007/s13225-012-0172-y.

Rivas Plata, E.; Lücking, R. \& Lumbsch, H.T. 2008. When family matters: an analysis of Thelotremataceae (Lichenized Ascomycota: Ostropales) as bioindicators of ecological continuity in tropical forests. Biodiversity and Conservation 17: 1319-1351.

Rivas Plata, E.; Lumbsch, H.T. \& Lücking, R. 2012. A new classification for the lichen family Graphidaceae s.lat. (Ascomycota: Lecanoromycetes: Ostropales). Fungal Diversity 52: 107-121.

Rivas Plata, E.; Parnmen, S.; Staiger, B.; Mangold, A.; Frisch, F.; Weerakoon, G.; Hernández M.J.E.; Cáceres, M.E.S.; Kalb, K.; Sipman, H.J.M.; Common, R.S.; Lücking, R. \& Lumbsch, H.T. 2013. A megaphylogeny of the lichen family Graphidaceae (Ascomycota: Lecanoromycetes: Ostropales). MycoKeys (in press).
Sipman, H.J.M.; Lücking, R.; Aptroot, A.; Chaves, J.L.; Kalb, K. \& Umaña Tenorio, L. 2012. A first assessment of the Ticolichen biodiversity inventory in Costa Rica and adjacent areas: the thelotremoid Graphidaceae (Ascomycota: Ostropales). Phytotaxa 55: 1-214.

Staiger, B. \& Kalb, K. 1999. Acanthothecis and other graphidioid lichens with warty periphysoids and paraphyses-tips. Mycotaxon 73: 69-134.

Staiger, B. 2002. Die Flechtenfamilie Graphidaceae: Studien in Richtung einer natürlicheren Gliederung. Bibliotheca Lichenologica 85: 1-526.

Wirth, M. \& Hale, M.E. 1963. The lichen family Graphidaceae in Mexico. Contributions from the United States National Herbarium 36: 63-119.

Wirth, M. \& Hale, M.E. 1978. Morden-Smithsonian Expedition to Dominica: the lichens (Graphidaceae). Smithsonian Contributions to Botany 40: 1-64. 